CLINICAL STUDY

\title{
Effects of 3-year GH replacement therapy on bone mineral density in younger and elderly adults with adult-onset GH deficiency
}

\author{
Mariam Elbornsson, Galina Götherström, Celina Franco, Bengt-Åke Bengtsson, Gudmundur Johannsson \\ and Johan Svensson \\ Department of Endocrinology, Research Centre for Endocrinology and Metabolism, Gröna Stråket 8, Sahlgrenska University Hospital, SE-413 45 \\ Göteborg, Sweden \\ (Correspondence should be addressed to M Elbornsson; Email: mariam.elbornsson@medic.gu.se)
}

\begin{abstract}
Objective: Little is known of the effects of long-term GH replacement on bone mineral content (BMC) and bone mineral density (BMD) in elderly GH-deficient (GHD) adults.

Design/patients/methods: In this prospective, single-center, open-label study, the effects of 3-year GH replacement were determined in $45 \mathrm{GHD}$ patients $>65$ years and in 45 younger control GHD patients with a mean age of 39.5 (s.E.m. 1.1) years. All patients had adult-onset disease and both groups were comparable in terms of number of anterior pituitary hormonal deficiencies, gender, body mass index, and waist:hip ratio.

Results: The mean maintenance dose of $\mathrm{GH}$ was $0.24(0.02) \mathrm{mg} /$ day in the elderly patients and 0.33 $(0.02) \mathrm{mg} /$ day in the younger GHD patients $(P<0.01)$. The 3 years of $\mathrm{GH}$ replacement induced a marginal effect on total body BMC and BMD, whereas femur neck and lumbar (L2-L4) spine BMC and BMD increased in both the elderly and the younger patients. The treatment response in femur neck BMC was less marked in the elderly patients $(P<0.05$ vs younger group). However, this difference disappeared after correction for the lower dose of $\mathrm{GH}$ in the elderly patients using an analysis of covariance. There were no between-group differences in responsiveness in BMC or BMD at other skeletal locations.

Conclusions: This study shows that GH replacement increases lumbar (L2-L4) spine and femur neck $\mathrm{BMD}$ and BMC in younger as well as elderly GHD patients. This supports the notion that long-term $\mathrm{GH}$ replacement is also useful in elderly GHD patients.
\end{abstract}

European Journal of Endocrinology 166 181-189

\section{Introduction}

GH deficiency (GHD) in hypopituitary adults results in multiple abnormalities in terms of body composition, bone mass, and glucose and lipid metabolism $(1,2,3)$. $\mathrm{GH}$ replacement normalizes most of these abnormalities in adult populations including patients of various ages $(1,2,3)$. The response to $\mathrm{GH}$ replacement may, however, vary in different subgroups of patients depending on the cause and severity of disease $(1,2,3)$ as well as on whether the disease was acquired in childhood or adulthood $(4,5)$.

$\mathrm{GH}$ secretion declines with increasing age $(6,7)$, but there are distinct differences between normal elderly subjects and elderly adults with structural hypothalamic-pituitary disease. The elderly GHD adults have lower $\mathrm{GH}$ secretion (8) and increased total body fat (9) compared with age-matched healthy subjects, whereas there is little difference in terms of lean mass (9). The results of several studies suggest that GH replacement in elderly GHD patients has approximately similar efficacy as that in younger GHD adults in terms of quality of life, body composition, and serum lipid pattern $(10,11,12,13)$.

Young GHD adults have reduced bone mineral content (BMC) and bone mineral density (BMD) (14). Short-term ( $\leq 12$ months) GH replacement in relatively young GHD adults results in unchanged or even decreased bone mass $(1,2,3,14)$, whereas long-term $\mathrm{GH}$ replacement improves BMC and BMD in open studies $(1,2,3,14,15,16)$. Meta-analyses, mainly of randomized $\mathrm{GH}$ treatment trials with relatively short duration, have shown either a moderate increase in lumbar spine BMD (17) or no change in BMD (18), which could have been due to relatively small sample size (18). In elderly GHD adults not receiving $\mathrm{GH}$ replacement, bone mass and density are approximately similar to that in healthy age-matched controls $(13,19$, 
20). Little is known whether GH replacement affects BMC and BMD in elderly GHD adults. In a recent review of studies on elderly GHD adults (21), no significant effect of GH replacement on BMD was observed, but previous studies have been few and of short duration and/or included relatively few patients (21).

In this single-center, open-labeled, prospective study, the effect of 3-year GH replacement on bone mass and density was determined in $45 \mathrm{GHD}$ patients $>65$ years at the beginning of study and in 45 matched younger control GHD patients. All patients had adult-onset GHD.

\section{Patients and methods}

\section{Patients}

Forty-five GHD adults >65 (mean age 68.7, range 65-75) years and 45 younger control GHD patients with a mean age of 39.5 (range 27-49) years were included in the period 1993-2006. The elderly and the younger patients were included contemporaneously. All patients had adult-onset disease and both groups were comparable in terms of number of anterior pituitary hormonal deficiencies, gender, body mass index (BMI), and waist:hip ratio (Table 1). All patients had known pituitary disease or other anterior pituitary hormonal deficiencies (Table 1). Patients with a history of Cushing's disease or acromegaly as the cause of the GHD were excluded since excess of cortisol or GH could

Table 1 Baseline characteristics of 45 elderly GHD patients and 45 younger control GHD patients. All patients had adult-onset pituitary disease. Values are shown as the mean (S.E.M.).

\begin{tabular}{|c|c|c|c|}
\hline & Elderly & Young & $P$ value \\
\hline$n$ & 45 & 45 & \\
\hline Men/women & $34 / 11$ & $34 / 11$ & \\
\hline Age (years) & $68.7(0.4)$ & $39.5(1.1)$ & $<0.001$ \\
\hline Body height $(\mathrm{cm})$ & $174.0(1.4)$ & $175.9(1.3)$ & 0.31 \\
\hline Body weight (kg) & $86.3(2.4)$ & $87.3(2.1)$ & 0.75 \\
\hline $\mathrm{BMI}\left(\mathrm{kg} / \mathrm{m}^{2}\right)$ & $28.5(0.7)$ & $28.3(0.7)$ & 0.84 \\
\hline Waist:hip ratio & $0.97(0.01)$ & $0.95(0.01)$ & 0.16 \\
\hline Dur. of hypopituitarism (years) & $6.7(1.1)$ & $2.1(0.2)$ & $<0.001$ \\
\hline \multicolumn{4}{|c|}{ Number of additional anterior pituitary deficiencies } \\
\hline Isolated GH deficiency & 2 & 3 & \\
\hline 1 Additional deficiency & 5 & 5 & \\
\hline 2 Additional deficiencies & 13 & 10 & \\
\hline 3 Additional deficiencies & 25 & 27 & \\
\hline $\begin{array}{l}\text { Total number of additional } \\
\text { deficiencies }\end{array}$ & 106 & 106 & \\
\hline \multicolumn{4}{|l|}{ Cause of pituitary deficiency } \\
\hline Pituitary adenoma ${ }^{a}$ & 38 & 32 & \\
\hline Empty sella & 2 & 4 & \\
\hline Craniopharyngioma & 2 & 3 & \\
\hline Hypophysitis & 1 & 2 & \\
\hline Other causes & 2 & 4 & \\
\hline
\end{tabular}

Dur., duration; a Patients with previous acromegaly or Cushing's disease were excluded. possibly affect the baseline characteristics as well as the response to $\mathrm{GH}$ replacement.

Thirty-eight patients in the elderly group and 35 of the younger patients had previously undergone pituitary surgery. Ten elderly and six younger patients had received radiotherapy. In 44 of both the elderly and the younger patients, the diagnosis of GHD was based on a peak $\mathrm{GH}<3 \mu \mathrm{g} / \mathrm{l}$ during a stimulation test (insulin/GHRH/glucagon). From each study group, one patient was diagnosed based on three additional anterior pituitary hormonal deficiencies and insulinlike growth factor 1 (IGF1) SDSs $<-2$ s.D. of predicted values. In addition, in these two patients, all plasma $\mathrm{GH}$ concentrations were $<0.33 \mu \mathrm{g} / \mathrm{l}$ during a $24-\mathrm{h}$ GH profile with sampling every $30 \mathrm{~min}$. When required, patients in both groups received adequate and stable therapy with glucocorticoids, thyroid hormone, gonadal steroids, and desmopressin. However, at baseline, two elderly women received estrogen replacement therapy, whereas nine women received estrogen replacement therapy in the younger group. None of the patients received treatment with calcium, vitamin D or bisphosphonates during the study period.

In the elderly group, one patient died during the study period (malignant brainstem tumor after 2.9 years) and two additional patients were excluded due to other adverse events (colonic cancer (10 months) and prostate cancer (3 months)). Furthermore, in the elderly group, four patients discontinued due to lack of compliance after $6,12,20$, and 33 months respectively and one patient moved to another part of Sweden after 27 months. In the younger group, two patients discontinued due to lack of compliance after 10 and 15 months respectively and one patient moved abroad after 14 months of GH replacement therapy. All patients were, however, retained in the statistical analysis according to the intention-to-treat approach used.

\section{Study protocol}

This is an ongoing, prospective, open-label treatment trial in adult GHD patients. In two patients of each group, the initial target dose of $\mathrm{GH}$ was $11.9 \mu \mathrm{g} / \mathrm{kg}$ per day $(0.25 \mathrm{IU} / \mathrm{kg}$ per week). The dose in these patients was gradually lowered and individualized during the first year of treatment. In all the remaining patients, the dose of GH was individualized from the beginning with the aim of normalizing IGF1 SDS (target range, 0 to +2 s.D. of predicted values) and body composition in each patient (22).

At baseline, and then after each year of $\mathrm{GH}$ replacement, physical and laboratory examinations were performed including measurements of body composition and bone mass. Dose titration and safety monitoring were performed every third month during the first year and every sixth month thereafter. Body weight was measured in the morning to the nearest 
$0.1 \mathrm{~kg}$, and body height and sitting height were measured to the nearest $0.01 \mathrm{~m}$. BMI was calculated as the weight in kilograms divided by the height in meters squared. Waist circumference was measured in the standing position with a flexible plastic tape placed midway between the lower rib margin and the iliac crest, and hip girth was measured at the widest part of the hip. No effort was made to influence the patients' physical activity level during the study period.

\section{Ethical considerations}

Informed consent was obtained from all patients. The study was approved by the Regional Ethics Review Board at the University of Gothenburg and the Swedish Medical Products Agency (Uppsala, Sweden).

\section{Body composition, BMC, and BMD}

Dual-energy X-ray absorptiometry (DXA) was used to measure lean soft tissue (LST) and body fat, as well as $\mathrm{BMC}$ and $\mathrm{BMD}$ in the total body, lumbar spine, and femur neck $(16,23)$. From the beginning of the study until the end of 1999, a LUNAR DPX-L scanner was used (Scanex, Helsingborg, Sweden). Software versions were changed several times (from 1.1 to lastly 1.35), version 1.33 being used during the major part of this period of the study. In-house precision error on the scanner used, as determined from duplicate examinations in ten healthy subjects, was $1.9 \%$ for total body BMC. The relative error for LST was $1.5 \%$. From January 2000, a LUNAR Prodigy scanner (Scanex) was used. Software versions were upgraded several times during data collection, from version 5.70 to 8.10. The precision of the scanner was estimated from repeated measurements on different days in 30 subjects with coefficients of variation (CV) of total body BMC of $1.4 \%$. Before the change of equipment in the end of 1999, the old and new DXA machines were cross calibrated in 30 subjects. In both study groups, 31 patients were included before the end of 1999 and 14 patients after January 1, 2000.

Daily quality control was performed according to manufacturer's protocol. A spine phantom was measured at least once a week. Every single spine phantom measurement was compared with a baseline value, based on a mean of ten repeated measurements. A maximum $1.5 \%$ deviation from the baseline value was accepted. A European phantom (COMAC-BME Quantitative Assessment of Osteoporosis Study Group) was measured once a year. BMD $z$-score, which is the difference in S.D. of age- and sex-matched healthy subjects, and $t$-score, which is the difference in S.D. of sex-matched young (20-39-year-old) healthy subjects, were determined using the Lunar DPX-L software program. The reference database used was the LUNAR USA reference population for the region examined.

\section{Biochemical analysis}

Serum IGF1 concentration, until June 2004, was determined by a hydrochloric acid-ethanol extraction RIA (Nichols Institute Diagnostics, San Juan Capistrano, CA, USA). Inter-assay and intra-assay CV were 5.4 and $6.9 \%$ respectively at a mean serum IGF1 level of $126 \mu \mathrm{g} / \mathrm{l}$ and 4.6 and $4.7 \%$ respectively at a mean serum IGF1 level of $327 \mu \mathrm{g} / \mathrm{l}$. From June 2004 to August 2006, serum IGF1 concentration was determined using a chemiluminescence immunoassay (Nichols Advantage; Nichols Institute Diagnostics) (24). From September 2006, serum IGF1 level was determined using an automated chemiluminescent assay system (IMMULITE 2500, Diagnostic Products Corp., Los Angeles, CA, USA). The individual serum IGF1 values were compared with age- and sex-adjusted values obtained from a reference population of 197 men and 195 women (25). The individual IGF1 SDSs could then be calculated (26).

\section{Statistical analysis}

All the descriptive statistical results are presented as the mean and s.e.m. Between-group differences during the 3-year treatment period were determined using a two-way repeated measures ANOVA of the percent change from baseline at all time points of the study. Within-group $P$ values were determined using a oneway ANOVA followed by Student-Newman-Keuls post hoc test. Between-group $P$ values at baseline and at the end of study were determined using ANOVA. All analyses were performed according to the intentionto-treat principle (using the carry forward principle). A two-tailed $P<0.05$ was considered significant.

\section{Results}

The elderly GHD patients and the younger control GHD patients were comparable in terms of gender, body height, body weight, BMI, waist circumference, waist: hip ratio, and number of anterior pituitary hormonal deficiencies (Table 1). The elderly patients had, however, longer duration of hypopituitarism compared with the younger patients (Table 1).

\section{GH dose and serum IGF1}

The daily dose of GH was increased during the first year of treatment and was then slightly reduced during the last year of $\mathrm{GH}$ replacement. At all time points of the study, the dose of GH was higher in the younger patients than in the elderly patients. Serum IGF1 levels increased during the first year of the study and then decreased slightly during the last year. The elderly patients had lower absolute level of serum IGF1 concentration than the younger patients, but there was no between-group 
Table 2 The dose of GH during 3-year GH replacement in 45 elderly GHD patients $>65$ years and 45 younger control GHD adults and the effects of this treatment on serum IGF1 level, IGF1 SDS and anthropometric measures. All values are shown as the mean (S.E.M.). The statistical analyses are based on ANOVA followed by Student-Newman-Keuls post hoc test.

\begin{tabular}{|c|c|c|c|c|c|c|}
\hline & & Baseline & 1 year & 2 years & 3 years & $\begin{array}{c}\boldsymbol{P} \text { value } \\
(0-3 \text { years })^{*}\end{array}$ \\
\hline Dose of $\mathrm{GH}$ (mg/day) & Elderly & $\begin{array}{l}0.15(0.01)^{\ddagger} \\
0.24(0.02)\end{array}$ & $\begin{array}{l}0.25(0.02)^{\ddagger, a} \\
0.37(0.03)^{a}\end{array}$ & $0.26(0.02)^{\dagger, a}$ & $0.24(0.02)^{\ddagger, a}$ & 0.52 \\
\hline Serum IGF1 $(\mu \mathrm{g} / \mathrm{l})$ & $\begin{array}{l}\text { Young } \\
\text { Elderly } \\
\text { Young }\end{array}$ & $\begin{array}{c}0.24(0.02) \\
83(7)^{\S} \\
143(11)\end{array}$ & $\begin{array}{l}170(12)^{\S, a} \\
283(20)^{\mathrm{a}}\end{array}$ & $\begin{array}{l}194(12)^{\S, a} \\
281(18)^{\mathrm{a}}\end{array}$ & $\begin{array}{l}187(12)^{\S, a} \\
266(16)^{a}\end{array}$ & 0.57 \\
\hline IGF1 SDS & $\begin{array}{l}\text { Elderly } \\
\text { Young }\end{array}$ & $\begin{array}{l}-1.12(0.15) \\
-1.38(0.23)\end{array}$ & $\begin{array}{l}0.69(0.23)^{\mathrm{a}} \\
1.52(0.41)^{\mathrm{a}}\end{array}$ & $\begin{array}{l}1.24(0.24)^{\mathrm{a}} \\
1.55(0.39)^{\mathrm{a}}\end{array}$ & $\begin{array}{l}1.12(0.24)^{\mathrm{a}} \\
1.28(0.35)^{\mathrm{a}}\end{array}$ & 0.15 \\
\hline Body height (cm) & $\begin{array}{l}\text { Elderly } \\
\text { Young }\end{array}$ & $\begin{array}{l}174.0(1.4) \\
175.9(1.3)\end{array}$ & $\begin{array}{l}173.9(1.4) \\
176.0(1.3)\end{array}$ & $\begin{array}{l}173.8(1.4) \\
176.0(1.2)\end{array}$ & $\begin{array}{l}173.8(1.4) \\
175.9(1.3)\end{array}$ & 0.29 \\
\hline Body weight $(\mathrm{kg})$ & $\begin{array}{l}\text { Elderly } \\
\text { Young }\end{array}$ & $\begin{array}{l}86.3(2.4) \\
87.3(2.1)\end{array}$ & $\begin{array}{l}85.0(2.3) \\
86.5(2.1)\end{array}$ & $\begin{array}{l}85.2(2.5) \\
87.4(2.1)\end{array}$ & $\begin{array}{l}84.9(2.4) \\
86.9(2.0)\end{array}$ & 0.50 \\
\hline BMI $\left(\mathrm{kg} / \mathrm{m}^{2}\right)$ & $\begin{array}{l}\text { Elderly } \\
\text { Young }\end{array}$ & $\begin{array}{l}28.5(0.7) \\
28.3(0.7)\end{array}$ & $\begin{array}{l}28.1(0.7) \\
28.0(0.7)\end{array}$ & $\begin{array}{l}28.2(0.7) \\
28.3(0.7)\end{array}$ & $\begin{array}{l}28.1(0.7) \\
28.1(0.6)\end{array}$ & 0.81 \\
\hline Waist circumference $(\mathrm{cm})$ & $\begin{array}{l}\text { Elderly } \\
\text { Young }\end{array}$ & $\begin{array}{r}100.6(1.9) \\
97.6(1.7)\end{array}$ & $\begin{array}{l}98.3(1.9)^{\mathrm{a}} \\
95.5(1.7)^{\Phi}\end{array}$ & $\begin{array}{l}98.2(0.011)^{a} \\
96.4(1.7)^{\|}\end{array}$ & $\begin{array}{l}97.9(0.012)^{\mathrm{a}} \\
95.5(1.7)^{\mathrm{a}}\end{array}$ & 0.30 \\
\hline Waist:hip ratio & $\begin{array}{l}\text { Elderly } \\
\text { Young }\end{array}$ & $\begin{array}{l}0.97(0.01) \\
0.95(0.01)\end{array}$ & $\begin{array}{l}0.95(0.01)^{\natural} \\
0.93(0.01)^{\|}\end{array}$ & $\begin{array}{l}0.94(0.01)^{a} \\
0.93(0.01)\end{array}$ & $\begin{array}{l}0.94(0.01)^{\mathrm{a}} \\
0.92(0.01)^{\mathrm{a}}\end{array}$ & 0.11 \\
\hline
\end{tabular}

*Between-group $P$ values (0-3 years) are based on an analysis of the percent change or change from baseline (for the dose of GH the percent change from the dose prescribed at the baseline visit), whereas other $P$ values are based on an analysis of the absolute values. ${ }^{\dagger} P<0.05$ vs younger patients; ${ }^{\ddagger} P<0.01$ vs younger patients; ${ }^{\S} P<0.001$ vs younger patients; ${ }^{\|} P<0.05$ vs baseline; ${ }^{\text {I }} P<0.01$ vs baseline; a $P<0.001$ vs baseline.

difference in the treatment response. Mean IGF1 SDS (adjustment for age and gender) was similar in both groups at all time points and was within the normal range ( \pm 2 s.D.) in both study groups (Table 2 ).

\section{Body composition}

Body height, body weight, and BMI did not change and were not significantly different between the two groups (Table 2). There were sustained reductions in waist circumference and waist:hip ratio in both groups without any between-group difference (Table 2).

As measured using DXA, body fat was reduced and LST was increased throughout the 3-year GH replacement without any between-group difference (Table 3).

\section{Bone mineral content}

At baseline, no differences in total body and lumbar (L2-L4) spine BMC were seen between the groups, whereas femur neck BMC was lower in the elderly compared with the younger GHD patients $(P<0.05)$. After 3 years of GH replacement, total body BMC had increased only in the younger patients, but there was no statistically significant difference in responsiveness between groups. Lumbar (L2-L4) spine BMC increased to a similar extent in both study groups. The increase in femur neck BMC was more marked in the younger patients $(P<0.05$ vs elderly group). At the end of study, femur neck BMC was still lower in the elderly patients $(P<0.05$; Table 3).

Table 3 Effects of 3-year GH replacement in 45 GHD adults $>65$ years and 45 younger control GHD adults on body composition and BMC as measured using dual-energy $\mathrm{X}$-ray absorptiometry. All values are shown as the mean (S.E.M.). The statistical analyses are based on ANOVA followed by Student-Newman-Keuls post hoc test.

\begin{tabular}{|c|c|c|c|c|c|c|}
\hline & & Baseline & 1 year & 2 years & 3 years & $\begin{array}{c}\boldsymbol{P} \text { value } \\
(0-3 \text { years })^{\star}\end{array}$ \\
\hline Body fat (kg) & $\begin{array}{l}\text { Elderly } \\
\text { Young }\end{array}$ & $\begin{array}{l}28.6(1.5) \\
28.7(1.3)\end{array}$ & $\begin{array}{l}26.0(1.5)^{\|} \\
25.9(1.4)^{\|}\end{array}$ & $\begin{array}{l}25.9(1.5)^{\|} \\
26.6(1.4)^{\|}\end{array}$ & $\begin{array}{l}25.5(1.5)^{\|} \\
26.2(1.3)^{\|}\end{array}$ & 0.06 \\
\hline Lean soft tissue $(\mathrm{kg})$ & $\begin{array}{l}\text { Elderly } \\
\text { Young }\end{array}$ & $\begin{array}{l}54.2(1.5) \\
55.3(1.4)\end{array}$ & $\begin{array}{l}55.2(1.4)^{\S} \\
56.8(1.4)^{\|}\end{array}$ & $\begin{array}{l}55.4(1.5)^{\S} \\
56.8(1.4)^{\|}\end{array}$ & $\begin{array}{l}55.5(1.5)^{\S} \\
56.9(1.4)^{\|}\end{array}$ & 0.80 \\
\hline Total body BMC (kg) & $\begin{array}{l}\text { Elderly } \\
\text { Young }\end{array}$ & $\begin{array}{l}2.95(0.09) \\
2.99(0.08)\end{array}$ & $\begin{array}{l}2.93(0.09) \\
3.03(0.07)\end{array}$ & $\begin{array}{l}2.95(0.09) \\
3.09(0.06)^{\S}\end{array}$ & $\begin{array}{l}2.96(0.09) \\
3.13(0.07)^{\|}\end{array}$ & 0.22 \\
\hline Lumbar (L2-L4) BMC (g) & $\begin{array}{l}\text { Elderly } \\
\text { Young }\end{array}$ & $\begin{array}{l}60.7(2.0) \\
60.8(1.7)\end{array}$ & $\begin{array}{l}61.3(2.1) \\
62.0(1.8)\end{array}$ & $\begin{array}{l}63.2(2.3)^{\|} \\
63.8(1.8)^{\|}\end{array}$ & $\begin{array}{l}64.2(2.4)^{\| \prime} \\
65.0(1.8)^{\|}\end{array}$ & 0.97 \\
\hline Femur neck BMC (g) & $\begin{array}{l}\text { Elderly } \\
\text { Young }\end{array}$ & $\begin{array}{l}5.12(0.16)^{\dagger} \\
5.51(0.11)\end{array}$ & $\begin{array}{l}5.22(0.15)^{\ddagger} \\
5.44(0.10)\end{array}$ & $\begin{array}{l}5.25(0.16)^{\dagger, t} \\
5.65(0.12)\end{array}$ & $\begin{array}{l}5.31(0.15)^{\dagger, \S} \\
5.80(0.15)^{\S}\end{array}$ & $<0.05$ \\
\hline
\end{tabular}

*Between-group $P$ values (0-3 years) are based on an analysis of the percent change from baseline, whereas other $P$ values are based on an analysis of the absolute values. ${ }^{\dagger} P<0.05$ vs younger patients; ${ }^{\ddagger} P<0.05$ vs baseline; ${ }^{\S} P<0.01$ vs baseline; ${ }^{\|} P<0.001$ vs baseline. 


\section{Bone mineral density}

Total body, lumbar (L2-L4) spine, and femur neck BMD are shown in Figs 1, 2, 3. At baseline, femur neck BMD and $t$-score were lower in the elderly GHD patients $(P<0.001$ vs younger GHD controls) while total body
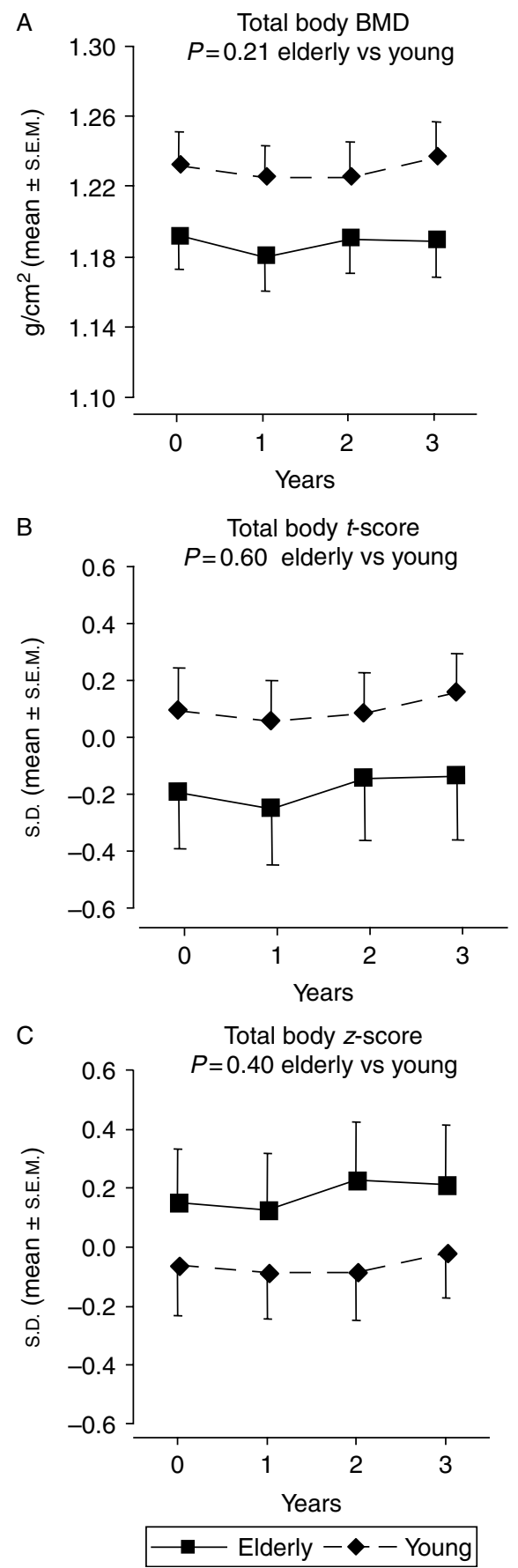

Figure 1 Total body (A) BMD, (B) $t$-score and (C) $z$-score during 3-year GH replacement in 45 GHD adults $>65$ years and 45 younger control GHD adults. The vertical bars indicate the S.E.M. for the mean values shown. There were no within- or between-group differences in terms of total body BMD, $t$-score, or $z$-score.
BMD and lumbar (L2-L4) spine BMD were similar in both groups. The elderly patients had, however, a higher mean lumbar (L2-L4) spine $z$-score than the younger patients at baseline $(P<0.05)$. At baseline, the $z$-score values were $\sim 0$ (predicted based on age and gender) in the elderly GHD group.

There was no difference between groups in the responses to 3-year GH replacement in terms of BMD at all skeletal sites measured. After 3 years, total body BMD was unchanged, whereas lumbar (L2-L4) spine BMD and femur neck BMD had increased within both study groups. At the end of study, femur neck BMD and $t$-score were still lower and lumbar (L2-L4) spine $z$-score was still higher in the elderly GHD patients compared with elderly GHD controls $(P<0.001, P<0.001$, and $P<0.05$ respectively).

\section{Analysis of covariance}

After correction for the longer duration of hypopituitarism using an analysis of covariance, the more marked reduction in the elderly patients in terms of femur neck BMC at baseline and the end of study lost statistical significance $(P=0.18$ and $P=0.06$ respectively). However, the between-group differences at baseline and the end of study in terms of femur neck BMD and $t$-score remained significant $(P<0.001)$.

When the higher dose of $\mathrm{GH}$ in the younger GHD patients was accounted for, the between-group difference in responsiveness in terms of femur neck BMC lost statistical significance $(P=0.22)$.

\section{Fractures}

No fractures were reported during the study period in any study group.

\section{Discussion}

This single-center, prospective, open-label treatment trial is, to our knowledge, the first study that has explored the long-term effects of $\mathrm{GH}$ replacement on bone mass and density specifically in elderly GHD adults. The 3-year GH replacement in patients $>65$ years with adult-onset GHD improved body composition and increased lumbar (L2-L4) spine and femur neck BMC and BMD.

A limitation of this study is that there was no untreated control group. However, we compared the effect of the 3-year GH replacement in elderly GHD patients with that in younger GHD adults. The use of $t$-scores and $z$-scores may also, to some extent, compensate for the lack of an untreated control group. Furthermore, at the end of 1999, the DXA machine used was changed. The new DXA was, however, calibrated to show as similar values as possible 
compared with the old DXA. In terms of $t$-scores and $z$-scores, the LUNAR USA reference population was used as the reference database throughout the study period. Finally, a similar number of patients in both study
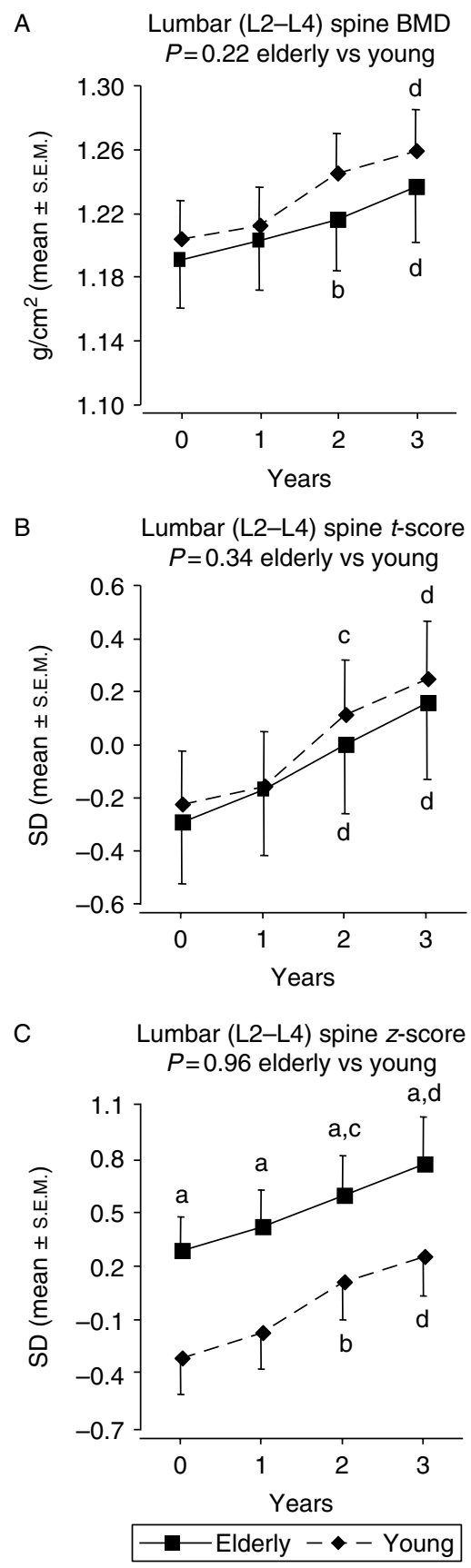

Figure 2 Lumbar (L2-L4) spine (A) BMD, (B) $t$-score and (C) $z$-score during 3-year $\mathrm{GH}$ replacement in $45 \mathrm{GHD}$ adults $>65$ years and 45 younger control GHD adults. The vertical bars indicate the S.E.M. for the mean values shown. Between-group $P$ values $(0-3$ years) are based on an analysis of the percent change or change from baseline, whereas other $P$ values are based on an analysis of the absolute values. ${ }^{\mathrm{a}} P<0.05$ vs younger patients; ${ }^{\mathrm{b}} P<0.05$ vs baseline; ${ }^{c} P<0.01$ vs baseline; ${ }^{d} P<0.001$ vs baseline. groups were measured using the old and the new DXA equipments.

Two patients in each group started GH replacement with a fixed dose of GH based on body weight that was gradually lowered and individualized. In the remaining patients, the dose of $\mathrm{GH}$ was individualized from the beginning of the study. In line with some previous observations $(13,27)$, this individualized GH replacement resulted in a lower dose of GH in the elderly GHD patients than in the younger GHD patients $(13,27)$. The 3-year GH replacement resulted in a mean IGF1 SDS within the normal physiological range ( \pm 2 s.D. $)$ in both groups. However, the mean IGF1 SDSs were in the upper normal range (between +1 and +2 s.D. of predicted values) after 2 years of $\mathrm{GH}$ replacement, and in both groups, the dose of $\mathrm{GH}$ was slightly reduced during the last year of the study. Furthermore, although the younger patients tended to have more marked increases in serum IGF1 concentration and IGF1 SDS than the elderly patients, there were no statistical differences between groups. This supports that elderly GHD patients are sensitive to $\mathrm{GH}$ and that a relatively low dose of GH can produce a significant increase in serum IGF1 concentration in this group of patients.

The 3-year GH replacement improved body composition in both study groups. There were sustained reductions in waist circumference, waist:hip ratio and total body fat without any between-group difference. LST was increased throughout the 3-year GH replacement in both groups. In line with this, several previous studies have demonstrated that $\mathrm{GH}$ replacement has approximately similar efficacy in terms of improvement of body composition in younger and elderly GHD patients $(10,12,13)$.

There was no between-group difference at baseline or in response to the 3-year GH replacement in total body and lumbar (L2-L4) spine BMC. The elderly patients had lower femur neck BMC than the younger control GHD patients at baseline and the younger patients had more marked increase in femur neck BMC in response to treatment. However, after correction for the longer duration of hypopituitarism in the elderly patients using an analysis of covariance, femur neck BMC did no longer differ between groups. Moreover, the more marked increase in femur neck BMC in the younger patients lost statistical significance when correcting for the higher dose of $\mathrm{GH}$ in the younger patients. Taken together, these findings indicate that BMC is approximately similar in elderly and younger GHD patients and that there is no major difference in responsiveness to GH replacement therapy.

There was no significant difference between groups in terms of total body BMD, $t$-score or $z$-score at baseline. The absolute levels of femur neck BMD and $t$-score were lower in the elderly patients. However, there was no difference between groups in femur neck $z$-score (BMD corrected for gender and age). This suggests that the lower femur neck BMD in the elderly patients was 
explained by the normal age-related decline in BMD. In the lumbar (L2-L4) spine, there was no between-group difference in BMD or $t$-score at baseline. However, lumbar (L2-L4) spine z-score was higher in the elderly compared with the younger GHD patients. This confirms that BMD, after correcting for the normal
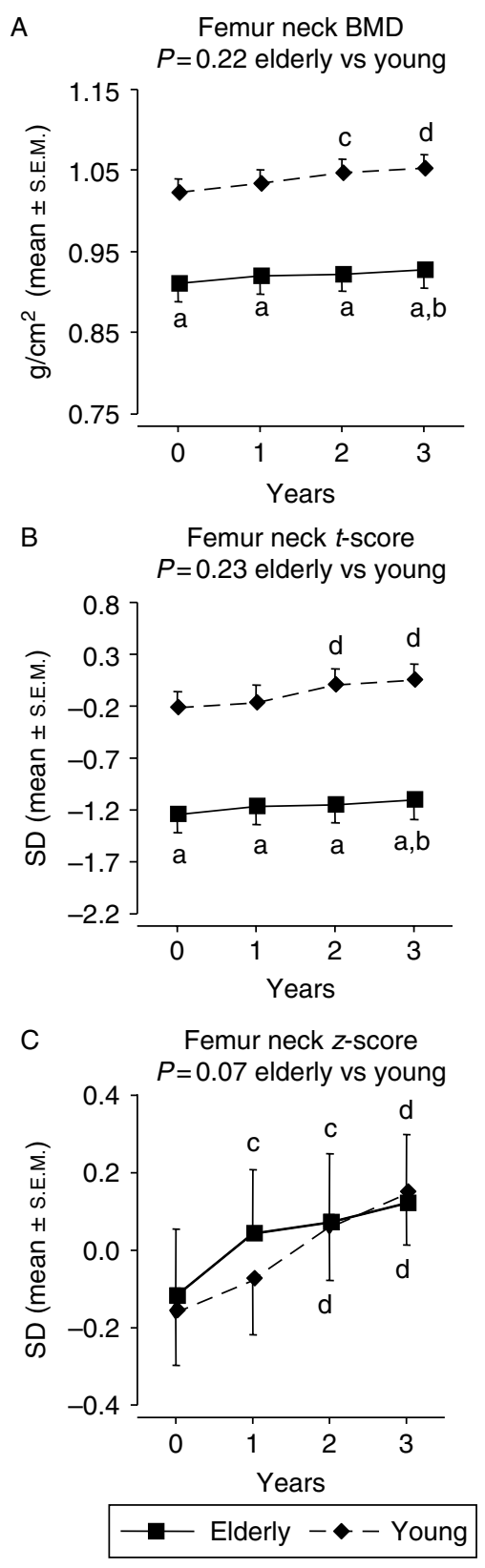

Figure 3 Femur neck (A) BMD, (B) $t$-score and (C) $z$-score during 3-year GH replacement in $45 \mathrm{GHD}$ adults $>65$ years and 45 younger control GHD adults. The vertical bars indicate the S.E.M. for the mean values shown. Between-group $P$ values ( $0-3$ years) are based on an analysis of the percent change or change from baseline, whereas other $P$ values are based on an analysis of the absolute values. ${ }^{\mathrm{a}} P<0.001$ vs younger patients; ${ }^{\mathrm{b}} P<0.05$ vs baseline; ${ }^{\mathrm{c}} P<0.01$ vs baseline; ${ }^{\mathrm{d}} P<0.001$ vs baseline. age-related decline, is higher in elderly than in younger GHD patients $(10,12,13)$.

The responsiveness to the 3-year GH replacement, at all skeletal sites measured, was similar in both study groups. In both groups, total body BMD was unchanged after 3 years, whereas lumbar (L2-L4) spine and femur neck BMD were increased. This demonstrates that $\mathrm{GH}$ replacement improves lumbar (L2-L4) spine and femur neck BMD in younger as well as elderly GHD patients. Furthermore, the lack of significant effect of the 3-year $\mathrm{GH}$ replacement on total body BMD in both groups is in some accordance with the notion that $\mathrm{GH}$ affects bone mass and density predominantly at weight-bearing skeletal locations such as the lumbar spine and the femur neck $(14,28)$. Therefore, the possibility cannot be excluded that $\mathrm{GH}$ indirectly increased bone mass by improving physical activity level and muscle strength. We did not record whether the 3-year GH replacement increased activity level or muscle performance, but no attempt was made to influence the patients' physical activity levels during the study period.

GHD adults not receiving $\mathrm{GH}$ replacement have increased risk of fractures $(29,30,31)$. It is not fully clear whether $\mathrm{GH}$ replacement can reduce the risk of fractures, but data based on Pfizer International Metabolic Database (KIMS) (31) as well as a Swedish multi-center study (32) may suggest a lower rate of fractures after $\mathrm{GH}$ repletion. In this study, no fractures were reported. However, the magnitudes of the increases in lumbar (L2-L4) spine and femur neck $\mathrm{BMD}$ in response to the 3-year GH replacement were lower than those previously observed after bisphosphonate treatment of postmenopausal women (33). Therefore, studies with larger study populations than the present one are needed to explore whether $\mathrm{GH}$ therapy can reduce the risk of fractures in elderly GHD patients.

GH replacement is motivated in elderly patients with impaired quality of life, body composition, and serum lipid pattern (34). In several studies, GH replacement has been shown to be similarly efficient in elderly and younger GHD adults in terms of improvement in these variables $(10,11,12,13)$. The results of this study in addition show approximately similar efficacy of GH replacement in terms of increased bone mass and density. Since elderly GHD patients do not have reduced BMD compared with age-matched healthy subjects, this will not be an indication for GH therapy in most elderly GHD patients. However, BMD will increase in elderly GHD patients receiving GH replacement for other reasons. This gives further support for the notion that $\mathrm{GH}$ replacement is also useful in elderly GHD patients.

The 3-year GH replacement increased lumbar (L2-L4) spine and femur neck BMD and BMC in elderly GHD adults. There are, however, distinct differences between elderly adults with GHD due to structural hypothalamic-pituitary disease and normal elderly subjects without severe GHD. Therefore, the extent to 
which long-term, low-dose GH treatment can improve bone mass in normal elderly subjects remains to be determined.

In conclusion, this single-center, prospective, openlabel treatment trial demonstrates that 3-year $\mathrm{GH}$ replacement increases lumbar (L2-L4) spine and femur neck BMC and BMD in elderly GHD patients. These increases were of similar magnitudes as those in the younger control GHD adults and give further support for the notion that $\mathrm{GH}$ replacement is useful in elderly GHD patients. It remains, however, to be investigated whether the increased BMC and BMD in response to $\mathrm{GH}$ replacement will reduce the risk of fractures in elderly GHD patients.

\section{Declaration of interest}

The authors declare that there is no conflict of interest that could be perceived as prejudicing the impartiality of the research reported.

\section{Funding}

This study was supported by the Swedish Research Council and the Sahlgrenska Academy at the University of Gothenburg.

\section{Acknowledgements}

We thank Ingrid Hansson, Annika Alklind, Ann-Charlotte Olofsson, Lena Wirén, and Sigrid Lindstrand at the Research Centre for Endocrinology and Metabolism for their skillful technical support.

\section{References}

1 de Boer H, Blok GJ \& Van der Veen EA. Clinical aspects of growth hormone deficiency in adults. Endocrine Reviews 199516 63-86. (doi:10.1210/er.16.1.63)

2 Carroll PV, Christ ER, Bengtsson B- $\AA$, Carlsson L, Christiansen JS, Clemmons D, Hintz R, Ho K, Laron Z, Sizonenko P, Sonksen PH, Tanaka T \& Thorner M. Growth hormone deficiency in adulthood and the effects of growth hormone replacement: a review. Growth Hormone Research Society Scientific Committee. Journal of Clinical Endocrinology and Metabolism 199883 382-395. (doi:10.1210/jc. 83.2.382)

3 Drake WM, Howell SJ, Monson JP \& Shalet SM. Optimizing GH therapy in adults and children. Endocrine Reviews 200122 425-450. (doi:10.1210/er.22.4.425)

4 Attanasio A, Lamberts S, Matranga A, Birkett M, Bates P, Valk N, Hilsted J, Bengtsson B-A \& Strasburger C. Adult growth hormone (GH)-deficient patients demonstrate heterogeneity between childhood onset and adult onset before and during human GH treatment. Journal of Clinical Endocrinology and Metabolism 1997 82 82-88. (doi:10.1210/jc.82.1.82)

5 Koranyi J, Svensson J, Götherström G, Sunnerhagen K, Bengtsson B- $\AA$ \& Johannsson G. Baseline characteristics and the effects of five years of growth hormone $(\mathrm{GH})$ replacement therapy in adults with GH deficiency of childhood or adulthood onset; a comparative, prospective study. Journal of Clinical Endocrinology and Metabolism 200186 4693-4699. (doi:10.1210/jc.86.10.4693)

6 Corpas E, Harman S \& Blackman M. Human growth hormone and human aging. Endocrine Reviews 199314 20-38. (doi:10.1210/ edrv-14-1-20)

7 Lamberts S, Van den Beld A \& Van der Lely A-J. The endocrinology of aging. Science $1997 \mathbf{2 7 8} 419-424$. (doi:10.1126/science.278. 5337.419)
8 Toogood A, O'Neill P \& Shalet S. Beyond the somatopause: growth hormone deficiency in adults over the age of 60 years. Journal of Clinical Endocrinology and Metabolism 199681 460-465. (doi:10. $1210 /$ jc.81.2.460)

9 Toogood A, Adams J, O'Neill P \& Shalet S. Body composition in growth hormone deficient adults over the age of 60 years. Clinical Endocrinology 199645 399-405. (doi:10.1046/j.1365-2265. 1996.8310842.x)

10 Monson J, Abs R, Bengtsson B-Å, Bennmarker H, FeldtRasmussen U, Hernberg-Stahl E, Thorén M, Westberg B, Wilton P \& Wuster C. Growth hormone deficiency and replacement in elderly hypopituitary adults. KIMS Study Group and the KIMS International Board. Pharmacia and Upjohn International Metabolic Database. Clinical Endocrinology 2000 53 281-289. (doi:10.1046/j.1365-2265.2000.01104.x)

11 Elgzyri T, Castenfors J, Hagg E, Backman C, Thorén M \& Bramnert M. The effects of GH replacement therapy on cardiac morphology and function, exercise capacity and serum lipids in elderly patients with GH deficiency. Clinical Endocrinology 200461 113-122. (doi:10.1111/j.1365-2265.2004.02080.x)

12 Götherström G, Bengtsson B-Å, Sunnerhagen K, Johannsson G \& Svensson J. The effects of five-year growth hormone replacement therapy on muscle strength in elderly hypopituitary adults. Clinical Endocrinology 200562 105-113. (doi:10.1111/j.13652265.2004.02181.x)

13 Franco C, Johannson G, Bengtsson B-Å \& Svensson J. Baseline charcteristics and effects of growth hormone therapy over two years in younger and older adults with adult onset GH deficiency. Journal of Clinical Endocrinology and Metabolism 2006 91 4408-4414. (doi:10.1210/jc.2006-0887)

14 Ohlsson $\mathrm{C}$, Bengtsson $\mathrm{B}-\AA$, Isaksson $\mathrm{O}$, Andreassen $\mathrm{T} \&$ Slootweg M. Growth hormone and bone. Endocrine Reviews 199819 55-79. (doi:10.1210/er.19.1.55)

15 Götherström G, Svensson J, Koranyi J, Alpsten M, Bosaeus I, Bengtsson B-A \& Johannsson G. A prospective study of 5 years of GH replacement therapy in GH-deficient adults: sustained effects on body composition, bone mass, and metabolic indices. Journal of Clinical Endocrinology and Metabolism $2001 \quad 86$ 4657-4665. (doi:10.1210/jc.86.10.4657)

16 Götherström G, Bengtsson B-Å, Bosaeus I, Johannsson G \& Svensson J. Ten-year GH replacement increases bone mineral density in hypopituitary patients with adult onset GH deficiency. European Journal of Endocrinology 2007156 55-64. (doi:10.1530/ eje.1.02317)

17 Davidson P, Milne R, Chase D \& Cooper C. Growth hormone replacement in adults and bone mineral density: a systematic review and meta-analysis. Clinical Endocrinology 200460 92-98. (doi:10.1111/j.1365-2265.2004.01935.x)

18 Hazem A, Elamin MB, Bancos I, Malaga G, Prutsky G, Domecq JP, Elraiyah TA, Abu Elnour NO, Prevost Y, Almandoz J, Zeballos-Palacios C, Velasquez R, Erwin PJ, Natt N, Montori VM \& Murad MH. Body composition and quality of life in adults treated with growth hormone therapy: a systematic review and meta-analysis. European Journal of Endocrinology 2012166 13-20. (doi:10.1530/EJE-11-0558)

19 Toogood A, Adams J, O'Neill P \& Shalet S. Elderly patients with adult-onset growth hormone deficiency are not osteopenic. Journal of Clinical Endocrinology and Metabolism 199782 1462-1466. (doi:10.1210/jc.82.5.1462)

20 Fernholm R, Bramnert M, Hagg E, Hilding A, Baylink D, Mohan S \& Thorén M. Growth hormone replacement therapy improves body composition and increases bone metabolism in elderly patients with pituitary disease. Journal of Clinical Endocrinology and Metabolism 200085 4104-4112. (doi:10.1210/jc.85.11. 4104)

21 Kokshoorn NE, Biermasz NR, Roelfsema F, Smit J, Pereira AM \& Romijn JA. GH replacement therapy in elderly GH-deficient patients: a systematic review. European Journal of Endocrinology 2011164 657-665. (doi:10.1530/EJE-10-1170) 
22 Johannsson G, Rosén T \& Bengtsson B-Å. Individualized dose titration of growth hormone $(\mathrm{GH})$ during $\mathrm{GH}$ replacement in hypopituitary adults. Clinical Endocrinology $1997 \mathbf{4 7} 571-581$. (doi:10.1046/j.1365-2265.1997.3271123.x)

23 Mazess R, Barden H, Bisek J \& Hanson J. Dual-energy X-ray absorptiometry for total-body and and regional bone-mineral and soft-tissue composition. American Journal of Clinical Nutrition 1990 51 1106-1112.

24 Brabant G, Von Zur Mühlen A, Wüster C, Ranke M, Kratzsch J, Kiess W, Ketelslegers J-M, Wilhelmsen L, Hultén L, Saller B, Mattsson A, Wilde J, Schemer R \& Kann P. Serum insulin-like growth factor I reference values for an automated chemiluminescence immunoassay system: results from a multicenter study. Hormone Research 2003 60 53-60. (doi:10.1159/ 000071871 )

25 Landin-Wilhelmsen K, Wilhelmsen L, Lappas G, Rosén T, Lindstedt G, Lundberg P-A \& Bengtsson B-A. Serum insulin-like growth factor $\mathrm{I}$ in a random population sample of men and women: relation to age, sex, smoking habits, coffee consumption and physical activity, blood pressure and concentrations of plasma lipids, fibrinogen, parathyroid hormone and osteocalcin. Clinical Endocrinology $1994 \mathbf{4 1}$ 351-357. (doi:10.1111/j.1365-2265. 1994.tb02556.x)

26 Svensson J, Johannsson G \& Bengtsson B-Å. Insulin-like growth factor-I in growth hormone-deficient adults: relationship to population-based normal values, body composition and insulin tolerance test. Clinical Endocrinology $1997 \mathbf{4 6} 579-586$. (doi:10. 1046/j.1365-2265.1997.1851001.x)

27 Feldt-Rasmussen U, Wilton P \& Jonsson P. Aspects of growth hormone deficiency and replacement in elderly hypopituitary adults. Growth Hormone $\mathcal{E}$ IGF Research 200414 (Suppl A) S51-S58. (doi:10.1016/j.ghir.2004.03.013)

28 Johannsson G, Rosen T, Bosaeus I, Sjostrom L \& Bengtsson B-Å. Two years of growth hormone $(\mathrm{GH})$ treatment increases bone mineral content and density in hypopituitary patients with adult-onset GH deficiency. Journal of Clinical Endocrinology and Metabolism $1996 \mathbf{8 1}$ 2865-2873. (doi:10.1210/jc.81.8. 2865)

29 Wüster C, Slenczka E \& Ziegler R. Increased prevalence of osteoporosis and arteriosclerosis in conventionally substituted anterior pituitary insufficiency: need for additional growth hormone substitution? Klinische Wochenschrift 199169 769-773. (doi:10.1007/BF01797616)

30 Rosén T, Wilhelmsen L, Landin-Wilhelmsen K, Lappas G \& Bengtsson B-Å. Increased fracture frequency in adult patients with hypopituitarism and GH deficiency. European Journal of Endocrinology 1997137 240-245. (doi:10.1530/eje.0.1370240)

31 Wüster C, Abs R, Bengtsson B- $\AA$, Bennmarker H, FeldtRasmussen U, Hernberg-Stahl E, Monson J, Westberg B \& Wilton P. The influence of growth hormone deficiency, growth hormone replacement therapy, and other aspects of hypopituitarism on fracture rate and bone mineral density. Journal of Bone and Mineral Research 2001 16 398-405. (doi:10.1359/jbmr.2001.16. 2.398)

32 Holmer H, Svensson J, Rylander L, Johannsson G, Rosén T, Bengtsson B-Å, Thorén M, Höybye C, Degerblad M, Bramnert M, Hägg E, Engström B, Ekman B, Thorngren K, Hagmar L \& Erfurth E. Fracture incidence in GH-deficient patients on complete hormone replacement including GH. Journal of Bone and Mineral Research 200722 1842-1850. (doi:10.1359/jbmr.070811)

33 Cummings S, Black D, Thompson D, Applegate W, BarrettConnor E, Musliner T, Palermo L, Prineas R, Rubin S, Scott J, Vogt T, Wallace R, Yates A \& LaCroix A. Effect of alendronate on risk of fracture in women with low bone density but without vertebral fractures: results from the Fracture Intervention Trial. Journal of the American Medical Association $1998 \mathbf{2 8 0} 2077-2082$. (doi:10.1001/jama.280.24.2077)

34 GH Deficiency Consensus Workshop Participants. Ho KK. Consensus guidelines for the diagnosis and treatment of adults with GH deficiency II: a statement of the GH Research Society in association with the European Society for Pediatric Endocrinology, Lawson Wilkins Society, European Society of Endocrinology, Japan Endocrine Society, and Endocrine Society of Australia. European Journal of Endocrinology 2007157 695-700. (doi:10.1530/EJE07-0631)

Received 12 October 2011

Revised version received 17 November 2011

Accepted 21 November 2011 